\title{
Cell per Well
}

National Cancer Institute

\section{Source}

National Cancer Institute. Cell per Well. NCI Thesaurus. Code C73636.

A unit of cell concentration expressed as a number of cells per a plate well. 